개에서 Pentoxifylline 첨가에 따른 동결정액 성상과 인공수정에 관한 연구

지달영*.김창근*이장희 **.박상재**.류일선**.류재원*.이주형*.정영채*방명걸* 중앙대학교 동물자원과학과, 중앙대학교 생명환경연구원*, 농촌진흥청 축산연구소**

\title{
Studies on Frozen Semen Characteristics Following Pentoxifylline Treatment and Artificial Insemination in Dog
}

\author{
Ji, D. Y.*, C. K. Kim*, J. H. Lee**, S. J. Park**, L. S. Ryu**, J. W. Ryu*, J. H. Lee*,
} Y. C. Chung* and M. G. Pang*

Department of Animal Science \& Technology and BET Research Institute, Chung-Ang University*, National Livestock Research Institute, R.D.A, Korea**

\begin{abstract}
The present study evaluated whether pentoxifylline added to the freezing extender could improve the sperm characteristics and function in canine frozen semen. Also the conception rate following AI with frozen-thawed semen was investigated. The beneficial effects of pentoxifylline supplementation were visible in motility, viability, acrosome reaction, and tail swelling patterns. Especially, highest sperm viability and function were obtained in the forzen semen supplemented with $1 \mathrm{mM}$ pentoxifylline. The follicle size measured by ultrasonography was $6.48 \mathrm{~mm}, 11.52 \mathrm{~mm}$ and $8.9 \mathrm{~mm}$ on 11,13 and 15 days after the onset of natural estrus, respectively and ovulation occurred on 13 and 15 days. The pregnancy rates in bitches inseminated with frozen semen on natural and induced estrus were $71.4 \%$ and $75.0 \%$, respectively. There was no significant difference between the pregnancy rates in bitches inseminated with frozen semen following natural and induced estrus, but the litter size was slightly increased in natural cycle.
\end{abstract}

(Key words : Pentoxifylline, Dog, CASA, Frozen Semen, AI)

\section{I. 서 론}

최근 애완견의 사육은 기하급수적으로 증가 하고 있으나, 인공수정의 번식기술에 대한 연 구는 다른 가축에 비하여 활발하게 진행되지 못하였다. 우수한 종견의 유전자원 보존 및 이 용에 관한 수요가 급속히 증가되고 있으며, 이 러한 수요의 증가에 따라 생식세포를 영구적으 로 보존하기 위한 정액의 동결과 이를 이용한
인공수정기술의 개발 필요성이 더욱 강조되고 있다. 인공수정은 우수한 유전자원을 효율적으 로 이용할 수 있는 방법으로 인식되어 왔으며, 동결정액의 이용은 시간과 장소의 구속 없이 번식이 가능하며 애견산업 발전에 크게 기여할 것으로 기대되고 있다.

개의 인공수정은 여러 연구자들에 의하여 신 선정 액(Farstad, 2000 ; Pinto 등, 1998), 저온보존 정액(Seager와 Fletcher, 1973), 동결정액(Gill 등,

*이 논문은 2000학년도 중앙대학교 학술연구비(일반연구비) 지원에 의한 것임.

Corresponding author:C. K. Kim, Dept. of Animal Sciences \& Technology, College of Industrial Sciences, Chung-Ang University, Ansung-Si, Kyunggi-Do 456-756, Korea. Tel : (031)670-3026, Fax : (031) 676-0062, E-mail : ckkim7503@cau.ac.kr 
1970)으로 연구되어 왔으며 동결정액을 이용한 인공수정은 현재까지 수태율이 낮음에도 불구 하고 장기간 보존할 수 있고 우수 종견의 활용 도를 높일 수 있다는 장점 때문에 더욱 많은 연구가 필요하다. 그러나 다양한 연구에도 불 구하고 애완견의 동결정액은 융해 후 활력, 생 존율, 정자 원형질막 기능, 첨체막 온전성 등의 동결융해로 인한 정액품질의 저하와 인공수정 수태율의 저하 등이 개선하여야 할 문제점으로 대두되고 있다.

Pentoxifylline은 free radicals로부터 형성된 산 화물을 제거하는 항산화제제의 작용이 있다고 보고되었다(Gavella 등, 1991). Brennan 등(1995) 은 동결정액에 pentoxifylline의 첨가로 운동성이 향상된다고 보고하였다. Methylxanthine에서 유래 된 pentoxifylline은 cyclic adenosine monophosphate (cAMP) 인산에테르가수분해효소(phosphodiesterase) 의 억제인자이다. Pentoxifylline의 작용이 세포 내 $\mathrm{cAMP}$ 를 높게 유지 시켜준다는 근거 하에 정자의 운동에 미치는 영향에 관하여 연구의 초점이 되어 왔다(Stefanovich, 1973). cAMP는 정자의 운동을 촉진시키며, hyperactivation 인자 로서, $\mathrm{ROS}$ 의 억제인자, 그리고 첨체 반응을 활 발히 하는 것으로 알려졌다.

인공수정은 자연 발정상태의 암컷을 사용할 수도 있지만 시간적 공간적 제약을 해결하고 보다 많은 번식기회를 갖고 번식효율을 더욱 개선하기 위해서 암컷을 원하는 시기에 발정 및 배란을 유도할 필요가 있다. 발정유기 방법 에서 Arnold 등(1989)은 암캐에 5 10일간 PMSG (20 IU/kg/day)와 $\mathrm{hCG}(500 \mathrm{IU})$ 를 처리하여 $50 \%$ 로의 임신율을 보고하였고, Shille 등(1989)은 발 정유기실험 처리 4일전에 testosterone을 주사하 고 diethlstilboestrol가 $5 \mathrm{mg}$ 함유된 tablet을 자궁 경관 입구에 장착 후 7일째 제거하고 발정전기 에 $\mathrm{LH}(5 \mathrm{mg}, \mathrm{i} . \mathrm{m}$.) 또는 FSH $10 \mathrm{mg}, \mathrm{i} . \mathrm{m}$.)를 투여 하여 효과적으로 발정이 유기됨을 보고하였다. Olson 등(1984)은 FSH 또는 PMSG의 병용 투여 와 Cain 등 $(1988,1989)$ 은 $\mathrm{GnRH}$ 투여방법을 보 고하였다. 이 등(2003)은 Clomofene, dromocriptine 단독 투여 그리고 $\mathrm{GnRH}+$ bromocriptine $/ \mathrm{GnRH}$ 혼합투여에 따른 발정유도방법은 임신율과 산
자 수에 영향을 미치지 않는 것으로 보고하였 으며, 신선정액을 이용한 인공수정방법은 자연 교미방법과 유사한 임신율과 산자수를 보였으 나, 동결정액을 이용한 인공수정 시에는 비교 적 낮게 나타났다고 보고하였다.

본 연구는 개에서 품종과 정액채취 방법에 따른 정액성상의 차이를 조사하고, 동결정액 제조시 pentoxifylline의 첨가가 융해 후 정액성 상에 미치는 영향을 조사하여 동결정액의 품질 을 향상시키고자 하였으며, 무발정기의 암캐를 발정 및 배란을 유도하여 효율적인 인공수정 방법과 수태율 향상방안을 찾음과 동시에 초음 파를 이용한 조기 임신진단방법을 제시코자 실 시하였다.

\section{II. 재료 및 방법}

\section{1. 공시동물}

본 실험의 공시동물은 좋은 유전자 부속농장 에서 사육되고 있는 2 3세의 Beagle, English cockers spanie, Collie, Greyhound, Shihtzu 품종 의 수컷 각각 1 두를 공시하였으며, 암컷으로는 Beagle, English cockers spanie, Greyhound, Shihtzu 및 잡견을 각각 $2,4,1,2$ 및 1 두씩 공시하였 다. 공시동물의 사육은 충분히 운동을 할 수 있는 쾌적한 환경의 사육장에서 사료는 제한급 여 하였으며 물은 자유급수 하였다.

\section{2. 정액채취}

정액채취는 1 주일에 1 2씩 수압법 및 인공 질법으로 채취하였고, 개의 심리적으로 안정을 취할 수 있는 정액채취실내에서 실시하였다. 정액 채취 전에 음경 포피 부위의 털을 제거하 여 정액 채취 시 이 물질의 혼입을 방지하였으 며, 음경포피 부위에 잔존되어 있는 이 물질은 $70 \%$ 에틸알콜 솜으로 제거 소독하였다. 음경은 생리식염수로 세척 후 발기와 돌출을 유도하여 돌출된 음경의 구선부위(bulbus glandis)를 잡고 압력을 가하면서 수압으로 인한 혈관의 파열을 피하면서 종견의 성적 자극을 유도한 조건에서 
정액채취를 실시하였다. 인공질법은 음경을 마 사지하여 발기와 돌출된 음경을 인공질에 삽입 한 후 음압을 걸어 정액을 채취하였다.

\section{3. 정액성상 검사}

수압법 또는 인공질법으로 채취된 개의 정액 은 육안적 검사와 현미경적 검사로 정액 성상을 조사하였다. 정액량, 색깔, 투명도, 점조 등을 육 안적 검사로 실시하였고, hemocytometer(Hausser Scientific, USA)를 이용한 정자의 농도, 정자의 형태 등을 현미경적 검사로 실시하였다.

\section{4. 동결정액의 제조 및 융해}

\section{(1) 동결희석액의 조성}

동결보존액인 $\mathrm{EYT}(\mathrm{Egg}-y o l k$ tris extender)는 $\operatorname{Rota}(1997)$ 방법에 따라 tris(hydroxymethyl) aminomethane $2.4 \mathrm{~g}$, citric acid $1.4 \mathrm{~g}$, glucose $0.8 \mathrm{~g}$, Na-benylpenicillin $0.06 \mathrm{~g}$, streptomycin sulphate $0.1 \mathrm{~g}$ 로 제조하였고, 난황은 당일 생산된 신선 난에서 난황을 분리하여 동결희석액에 $20 \%(\mathrm{v} / \mathrm{v})$ 농도로 첨가하였다. 교반이 끝난 $\mathrm{EYT}$ 동결희석 액은 $1200 \times \mathrm{g}$ 에서 30 분간 원심 분리하여 표면 의 지질층을 제거하고 난황괴를 제외한 상층액 을 취하여 사용하였다.

\section{(2) Pentoxifylline의 첨가}

2차 동결희석액은 $\mathrm{EYT}$ 에 glycerol $5 \%, \mathrm{OEP}$ (Equex STM, NOVA Chemical, USA) 0.5\%를 첨 가하여 교반 후 사용하였고, pentoxifylline(Sigma, $\mathrm{USA}$ )은 최종농도가 각각 $0 \mathrm{mM}, 1 \mathrm{mM}, 3 \mathrm{mM}$ 이 되도록 첨가하였다.

\section{(3) 정액 동결과 융해}

채취된 정액의 성상을 조사한 후 $700 \times \mathrm{g}$ 에서 3 분간 원심분리를 실시하여 상층액을 제거하고 미리 준비한 1 차 희석액으로 희석하여 $5^{\circ} \mathrm{C}$ 까지 냉각시킨 후 동일온도의 2차 희석액으로 30 분 동안 3회로 분할 참가하였고, 2 차 희석 후 20 분간 glycerol 평형을 유도 후 straw당 총 정자 수가 $50 \times 10^{6}$ 되게 포장하여 액체질소 표면 7 $\mathrm{cm}\left(-80^{\circ} \mathrm{C}\right)$ 위에서 10 분간 예비동결 후 액체질 소에 침지하여 동결정액 제조를 완료하였다. 동결정액의 융해는 $37^{\circ} \mathrm{C}$ 의 온수에서 20 초간 동 안 실시하였다.

\section{5. 동결융해 정자의 검사}

(1) 정액의 전처리

동결정액을 $37^{\circ} \mathrm{C}$ 의 온수에서 20 초간 융해 후 washing media로 $600 \times \mathrm{g}$ 에서 5 분간 원심분리 하였다. 상층액을 제거하고 정자 펠렛을 각 검 사방법에 적합한 농도로 재부유하여 사용하였다.

\section{(2) 정자의 운동양상 검사}

정자의 운동양상 분석은 CASA(Computer assisted sperm analysis)로 실시하였다. 원정액은 동결 전 일부를 이용하여 동결전의 운동성을 검사하고, 동결 후 융해한 정자는 washing media로 처리 후 정액 $10 \mu \ell$ 를 미리 $37^{\circ} \mathrm{C}$ 로 가온 된 Markler counting chamber (Sefi medical instrument, Israel) 위에 떨어뜨린 후 CCD 카메라(Toshiba, Japan) 가 장착된 광학현미경(Olympus, Japan)에 연결 된 CASA(SAIS system, Sais plus version 10.1, Medical Supply, Korea)를 이용하여 검사하였다. 측정 방법은 Takagi 등(2001)의 방법에 준하여 실시하였고, 정자 운동양상의 항목으로서 운동 성(motility), 직선운동속도(staight line velocity: $\mathrm{VLS}$ ), 곡선운동속도(curve linear velocity: VCL), 곡선경로 선형도(linearity: $\mathrm{LIN}$ ), 측두이동거리 (amplitude of lateral head displacement: ALH), 평균경로속도(average-path velocity: VAP)을 검 사하였다.

\section{(3) 정자의 원형질막 검사}

HOST(hypoosmotic swelling test)는 Kumi-Diaka (1993)의 방법에 준하여 실시하였다. Fructose $13.50 \mathrm{~g}$, sodium citrate $7.35 \mathrm{~g}$ 을 증류수 $1000 \mathrm{ml}$ 에 녹여 최종삼투압이 $60 \mathrm{mOsm} / \mathrm{Kg}$ 되게 제조 하여 실험에 이용하였다. 각 처리 구의 정액을 washing media와 혼합한 후 $500 \times \mathrm{g}$ 에서 5 분간 원심분리 한 다음 농도를 $20 \times 10^{6} / \mathrm{ml}$ 으로 조절 한 후 정액 $100 \mu l$ 를 $1.5 \mathrm{ml}$ eppendorf tube에 넣 
고 미리 준비한 저삼투압 용액 $900 \mu l$ 를 첨가하 여 교반 후 $37^{\circ} \mathrm{C}$ 에서 30 분간 배양하였다. 배양 후 $10 \mu$ 정도를 취하여 swelling을 위상차 현미 경하에서 조사하였다.

\section{(4) 정자의 생존율}

생존율 조사를 위한 염색방법은 Garner 등 (1994)의 방법에 준하여 실시하였다. SYBR-14 sperm live/dead Kit(FertilightTM Kit, Molucular Probes, USA)는 SYBR-14는 anhydrous dimethyl sulfoxide(DMSO, Sigma, USA)에 $1 \mathrm{mg} / \mathrm{ml}$ 을 함 량 함유한 stock solution 이었고 $\mathrm{PI}$ (propidium iodide)는 Tyrodes salt solution에 $2 \mathrm{mg} / \mathrm{ml}$ 가 함유 되었다. 생사염색은 SYBR-14 stock solution을 $\mathrm{DMSO}$ 를 100 배 희석하여 만든 working solution $2.7 \mu \ell$, 미리 제조한 PI $2 \mu l$ 의 washing media를 전 처리된 정액에 넣고 $37^{\circ} \mathrm{C}$ 의 heating-block에 서 30 분간 배양 후 형광현미경(Hund Wetzlar $\mathrm{H} 600$, Germany)에서 관찰하였다. 광선은 405 $\mathrm{nm}$-dand filter를 통과하고 SYBR-14형광의 발광 을 $455 \mathrm{~nm}$-dicrmic 반사경과 $475 \mathrm{~nm}$ barrier filter 현미경위에서 200 개의 정자를 3 회 반복 관찰하 였다.

\section{(5) 정자의 첨체막 온전성}

정자의 염색은 Spermac kit(Stain Enterprises, Onderstepoort, South Africa)를 이용하여 수행하 였으며, washing media로 전 처리된 각 처리 구 의 정액을 슬라이드에 도말하여 공기 중에서 건조한 후 fixative I 로 고정하고 슬라이드를 증류수로 세척 후 stain solution A 5분, stain solution $\mathrm{B}$ 에 1 분, stain solution $\mathrm{C}$ 에 1 분씩 3 단 계로 염색하였다. 각 염색 단계마다 증류수로 세척하였고 공기 중에서 건조시켰다. 염색된 슬라이드는 광학현미경에서 1000 배의 배율로 슬라이드당 200 개 이상 정자의 첨체를 판독하 였다.

\section{6. 발정유기 및 인공수정}

Ring-CIDR은 기존 Shille 등(1989)의 tablet 대 신 링모양의 약물방출링으로 Diethylstilbestrol를
방출하는 기구이다. 이 Ring-CIDR를 이용하기 위해 4개월 이전에 발정한 경험이 없는 암캐에 게 Ring-CIDR/DES(Controled intravaginal drug release/Diethylstilbestrol, 좋은 유전자, 한국)를 질 내에 $7 \sim 10$ 일간 장치하는 동안에 외음부가 종창되고 출혈이 확인되면 이 날을 Day 0(proestrus)으로 정하고 Day 3일째에 Ring-CIDR/DES 를 제거하였다. Day 5일째에 hCG 1000 IU 또 는 $\mathrm{FSH} 50 \mathrm{mg}$ 을 1 회 근육주사하고 필요시 Day 8 일째에 $\mathrm{GnRH}\left(30^{\sim} 50 \mu \mathrm{g}\right)$ 를 주사하였다. 교배적 기는 외음부 종창이 작아지고 출혈분비액이 암 갈색으로 바뀌는 시기에 질점막상피세포 도말 검사와 초음파진단기를 이용한 난포크기의 변 화로 인공수정 적기로 판단하였다. 자연발정군 과 Ring-CIDR 처리군의 인공수정 적기를 규명 하기 위하여 초음파진단기를 이용하여 난소내 난포발달 상태를 측정하였다. 자연적으로 발정 이 개시된 Beagle 2두, Shihzu 1두, Grey hound 1두, English cockers spanie 1두 및 잡견 2두와 Ring-CIDR 처리한 Beagle 1두 및 English cockers spanie 3 두에 대해서 초음파진단기 $3.5 \mathrm{MHz}$ probe, SA $600 \mathrm{~S}$, Medison, Korea)를 이용하여 발정개시 후 11 일째부터 15 일까지 초음파 화상으로 난소 내 난포크기 변화를 조사하였고, 난포 상태를 확인한 다음 융해한 정액으로 인공수정을 실시 하였다. 인공수정방법 암컷을 보정 후 양쪽 음 순사이로 질경을 밀어 넣고 수직방향으로 자궁 경관 입구까지 유도 후 주입기를 이용하여 자 궁경관 심부에 주입하였다.

\section{7. 조기 임신진단}

발정유기한 개체에 대하여 첫 교배 후 20 일 전후에 임신진단은 $3.5 \mathrm{MHz}$ probe가 장착된 초 음파기를 이용하여 실시하였으며, 태낭의 크기 변화를 5 일 간격으로 3 회 측정하였다.

\section{8. 통계 분석}

정자의 동결·융해 후 정자의 기능검사 결과 에 대한 유의성 검정은 SAS의 Duncan's multiple range test에 의해 실시하였다. 


\section{III. 결과 및 고찰}

\section{1. 품종 및 정액 채취방법간의 정액 성상}

품종별 정액성상을 조사한 결과는 Table 1 과 같다. Beagle, English cockers spanie, Collie 및 Grey hound의 정액량과 정자 수에서 차이가 없 었으나, Shihtzu에서 정액량과 정자수가 다소 적었다. 그러나 품종별 정액성상간에 차이를 알기 위해서는 동일개체의 반복도 필요하고 품 종내 개체수가 많아야 하겠다. 개의 체중에 따 라 정액량이 차이가 있는 것으로 Gunzel(1986) 는 보고한 바 있다.

정액채취방법간의 정액성상은 Table 2에 보 는 바와 같다. 수압법과 인공질법을 이용하여 채취된 정액량은 $3.9 \pm 1.9 \mathrm{ml}$ 와 $3.6 \pm 1.3 \mathrm{ml}$ 로 차 이가 없었다. 이 결과는 Harrop(1954)이 인공질 법이 우수하다고 한 것과 Boucher 등(1958)이 수압법이 우수하다고 한 보고와는 다른 결과였 다. 한편 정자농도는 수압법이 인공질법 보다 높았고 그 결과 총 정자수도 수압법에서 높았 다. 그러나 정자 운동성과 생존성은 두 방법간 에 차이가 없었다.
2. 동결희석액 조성에 따른 동결융해 정자의 운동성

Table 3 에서와 같이 동결 전 $5^{\circ} \mathrm{C}$ 검사 시에 는 $\mathrm{OEP}$ 첨가로 운동성의 변화 향상이 없었으 나 동결 융해 후에는 $\mathrm{OEP}$ 첨가한 희석액에서 활발한 운동성 향상이 나타났다. 개 동결정자 의 인공수정 효과에 있어서 가장 중요한 요인 중의 하나가 희석액이다. 그러나 아직 최적 희석 액의 조성은 보고되어 있지 않다(Olar 등, 1989). 가장 많이 이용되고 있는 기본 희석액으로서 Tris-glucose-citric acid(Foote, 1964), Tris-fructosecitric $\operatorname{acid}($ Gill 등, 1970) 및 $3 \sim 4 \%$ glycerol이 함유된 egg yolk tris buffer (Olar, 1989)이다. 최 근 개발된 동결희석액 중 $2 \%$ glycerol을 함유 한 $0.1 \mathrm{M} /$ Tris buffer는 개 정자에서 융해 후 양호한 운동성을 보여주었다(England와 Allen, 1992). 본 실험의 결과에서 fructose, $5 \%$ glucose 및 $8 \%$ glycerol 첨가보다도 추가로 $\mathrm{OEP}$ 를 첨가 한 군에서 융해 후 운동성이 높았던 것이 이들 보고를 뒷받침해주는 결과라고 볼 수 있겠다. 특히 Rota 등(1997)은 Tris, glucose 및 난황을 첨가한 동결희석액에 $\mathrm{OEP}$ 추가 첨가에서 융해

Table 1. Semen characteristics sperm among dog breeds

\begin{tabular}{cccccc}
\hline Breeds* & $\begin{array}{c}\text { Volume } \\
(\mathrm{ml})\end{array}$ & $\begin{array}{c}\text { Concentration } \\
\left(\times 10^{6} / \mathrm{ml}\right)\end{array}$ & $\begin{array}{c}\text { Total sperm } \\
\left(\times 10^{6}\right)\end{array}$ & $\begin{array}{c}\text { Progressive } \\
\text { motility }(\%)\end{array}$ & $\begin{array}{c}\text { Viability } \\
(\%)\end{array}$ \\
\hline \hline $\mathrm{A}$ & $4.6 \pm 3.1$ & $130.0 \pm 27.3$ & $598.0 \pm 140.5$ & $78.8 \pm 7.4$ & $88.1 \pm 3.2$ \\
$\mathrm{~B}$ & $3.7 \pm 1.3$ & $108.2 \pm 51.7$ & $399.3 \pm 142.3$ & $79.9 \pm 6.7$ & $85.8 \pm 2.4$ \\
$\mathrm{C}$ & $4.6 \pm 3.2$ & $215.4 \pm 37.4$ & $349.7 \pm 246.7$ & $82.3 \pm 3.3$ & $87.2 \pm 3.1$ \\
$\mathrm{D}$ & $3.4 \pm 0.5$ & $173.7 \pm 46.6$ & $384.2 \pm 270.8$ & $88.3 \pm 4.5$ & $90.4 \pm 6.3$ \\
$\mathrm{E}$ & $3.0 \pm 1.2$ & $73.0 \pm 32.2$ & $216.0 \pm 140.5$ & $80.4 \pm 4.3$ & $85.6 \pm 4.6$ \\
\hline
\end{tabular}

Mean \pm SD.

* A : Beagle, B : English cockers spanie, C : Collie, D : Grey hound, E : Shihtzu.

Table 2. Semen characteristics between semen collection method

\begin{tabular}{lccccc}
\hline \multicolumn{1}{c}{ Method } & $\begin{array}{c}\text { Volume } \\
(\mathrm{ml})\end{array}$ & $\begin{array}{c}\text { Concentration } \\
\left(\times 10^{6} / \mathrm{m} \ell\right)\end{array}$ & $\begin{array}{c}\text { Total sperm } \\
\left(\times 10^{6}\right)\end{array}$ & $\begin{array}{c}\text { Progressive } \\
\text { motility }(\%)\end{array}$ & $\begin{array}{c}\text { Viability } \\
(\%)\end{array}$ \\
\hline \hline Digital manipulation & $3.9 \pm 1.9^{*}$ & $206.7 \pm 18.5$ & $441.6 \pm 157.5$ & $79.7 \pm 7.0$ & $89.1 \pm 2.7$ \\
Artificial vagina & $3.6 \pm 1.3$ & $157.2 \pm 32.7$ & $387.3 \pm 139.3$ & $81.2 \pm 5.7$ & $80.7 \pm 3.0$ \\
\hline
\end{tabular}

* Mean \pm SD. 
후 정자 활력의 향상은 없었으나 융해 후 시간 경과에 따라 활력이 높게 유지되었고 융해 후 첨체 온전성을 갖는 정자비율이 높다고 하였 다.

Table 3. Sperm motility in frozen semen diluted in 3 different extenders

\begin{tabular}{|c|c|c|}
\hline \multirow{2}{*}{ Extenders } & \multicolumn{2}{|c|}{ Motility(\%) } \\
\hline & Before freezing & After thawing \\
\hline EYTGG $^{1)}$ & $82.0 \pm 3.3$ & $37.0 \pm 7.1^{\mathrm{b}}$ \\
\hline EYTFG $^{2)}$ & $84.0 \pm 4.1$ & $45.0 \pm 5.4^{\mathrm{b}}$ \\
\hline EYTFGO $^{3)}$ & $86.0 \pm 3.5$ & $58.0 \pm 4.4^{\mathrm{a}}$ \\
\hline \multicolumn{3}{|c|}{$\begin{array}{l}\text { Mean } \pm \text { SD. } \\
\text { a,b Means with different superscripts differ significantly } \\
(\mathrm{P}<0.05) \text {. }\end{array}$} \\
\hline \multicolumn{3}{|c|}{$\begin{array}{l}\text { 1) Tris } 2.422 \mathrm{~g} \text {, citric acid } 1.152 \mathrm{~g} \text {, glucose } 0.901 \mathrm{~g} \text {, egg } \\
\text { yolk } 20 \%, 8 \% \text { glycerol in } 100 \mathrm{ml}\end{array}$} \\
\hline \multicolumn{3}{|c|}{$\begin{array}{l}\text { 2) Tris } 3.025 \mathrm{~g} \text {, citric acid } 1.700 \mathrm{~g} \text {, fructose } 1.250 \mathrm{~g} \text {, egg } \\
\text { yolk } 20 \%, 5 \% \text { glycerol in } 100 \mathrm{ml}\end{array}$} \\
\hline \multicolumn{3}{|c|}{$\begin{array}{l}\text { Tris } 3.025 \mathrm{~g} \text {, citric acid } 1.700 \mathrm{~g} \text {, fructose } 1.250 \mathrm{~g} \text {, egg } \\
\text { yolk } 20 \%, 5 \% \text { glycerol, } 0.5 \% \text { OEP in } 100 \mathrm{ml}\end{array}$} \\
\hline
\end{tabular}

\section{Pentoxifylline 첨가와 정액성상}

\section{(1) 정자활력과 운동양상}

동결희석액에 pentoxifylline을 첨가전의 액상 정액과 동결융해 후의 정자의 운동양상을 조사 한 결과는 Table 4 와 같다. 채취 직후, $0 \mathrm{mM}, 1$ $\mathrm{mM}$ 과 $3 \mathrm{mM}$ 이 첨가된 동결정액의 융해 후 정 자활력은 각각 $70.2,46.4,56.4,47.2 \%$ 로 $1 \mathrm{mM}$ 의 처리구가 다른 첨가구에 비해 유의적으로
높았다. 또한 $1 \mathrm{mM}$ 첨가에서 $\mathrm{VCL}, \mathrm{VAP}, \mathrm{LIN}$ 및 $\mathrm{ALH}$ 가 대조구에 비해 다소 높아 졌으며 한 편 $3 \mathrm{mM}$ 에서는 $\mathrm{VCL}, \mathrm{VSL}$ 과 $\mathrm{LIN}$ 이 대조구 보다 크게 낮아졌다. Pentoxifylline은 phosphodiesterase inhibitor로서 알려져 있다 (Yovich, 1993). 정자 에 처리시 전진운동 $\mathrm{VCL}$ 과 $\mathrm{ALH}$ 를 증진시키며 (Rees 등, 1990), 항산화작용으로서 ROS를 감소 시키는 것으로 보고되어 있다. 또한 정액동결 전 처리 시에 융해 후 정자운동성 회복율이 개 선됨이 보고되어 있으며(Wang 등, 1993), 사람 에선 $1 \mathrm{mM}$ 에서 전진운동의 증가가 보고되었다 (Brennan과 Holden, 1995). 한편 Esteves 등(1998) 은 사람정자에서 $5 \mathrm{mM}$ 첨가 시 융해 후 활력 의 개선이 있었으나 그 외 다른 운동양상에는 영향이 없었으며 ARIC(Acrosome Reaction to Ionophore Challenge) 검사에 대한 첨체반응 개 선을 보고하였다. Nassar 등(1999)은 사람에서 1 $\mathrm{mM}$ 처리에서 $\mathrm{VCL}, \mathrm{ALH}$ 가 크게 개선되고 $\mathrm{LIN}$ 은 감소됨을 보고하였다. Mckinney 등(1996)은 $7.2 \mathrm{mM}$ 처리에서 ROS의 현저한 감소와 더불어 지질과 산화가 감소됨을 보고하였다. Maxwell 등(1995)은 면양에서 동결전 $15 \mathrm{mM}$ 처리에서 운동성개선, $1 \sim 2 \mathrm{mM}$ 처리에서 첨체 온전성의 향상이 있었으며 $15 \mathrm{mM}$ 처리 정액의 자궁내 주 입의 임신율은 대조구와 차이가 없다고 하였다.

본 연구에서 $1 \mathrm{mM}$ 처리에서 양호한 결과를 얻은 것은 이들과 일부 유사하였다. 그러나 pen- toxifylline의 최적수준은 보고자간 다소 차 이가 있음을 알 수 있다.

Table 4. Effect of pentoxifylline concentration on sperm motion parameters after thawing

\begin{tabular}{lcrcr}
\hline \multirow{2}{*}{ Parameters* } & \multirow{2}{*}{$\begin{array}{c}\text { Fresh } \\
\text { semen }\end{array}$} & \multicolumn{3}{c}{ Pentoxifylline $(\mathrm{mM})$} \\
\cline { 3 - 5 } & $70.2 \pm 3.7$ & $46.4 \pm 5.9^{\mathrm{b}}$ & $56.4 \pm 7.6^{\mathrm{a}}$ & \multicolumn{1}{c}{3} \\
\hline \hline MOT $(\%)$ & $34.1 \pm 5.2$ & $22.8 \pm 9.9$ & $25.3 \pm 8.3^{\mathrm{b}}$ \\
$\operatorname{VCL}(\mu \mathrm{m} / \mathrm{sec})$ & $37.3 \pm 4.5$ & $11.1 \pm 9.0$ & $12.4 \pm 4.6$ & $20.4 \pm 3.8$ \\
$\operatorname{VSL}(\mu \mathrm{m} / \mathrm{sec})$ & $36.1 \pm 4.0$ & $14.6 \pm 8.9$ & $16.1 \pm 5.2$ & $9.6 \pm 3.0$ \\
$\operatorname{VAP}(\mu \mathrm{m})$ & $49.3 \pm 5.7$ & $42.5 \pm 11.8$ & $43.7 \pm 12.0$ & $40.1 \pm 6.4$ \\
LIN $(\%)$ & $3.6 \pm 0.9$ & $3.4 \pm 0.4$ & $3.7 \pm 0.3$ & $3.5 \pm 0.6$ \\
ALH $(\mu \mathrm{m})$ & &
\end{tabular}

${ }^{\mathrm{a}, \mathrm{b}}$ Means with different superscripts differ significantly $(\mathrm{P}<0.05)$.

* MOT : motility, VCL : curve linear velocity, VSL : straight line velocity, VAP : average path velocity, LIN : linearity, ALH : amplitude of lateral head displacement. 


\section{(2) 정자의 HOST}

Pentoxifylline 첨가된 동결정액의 정자 HOST 에서 나타난 미부팽창정자의 비율은 Table 5와 같다. 동결융해후의 HOST 결과는 $1 \mathrm{mM}$ 의 처 리구가 $59.47 \%$ 로 다른 첨가수준 $0 \mathrm{mM}, 3 \mathrm{mM}$ 처 리구의 $53.67,53.87 \%$ 보다 높게 나타났다. 동 결융해후 HOST 결과는 동결정액의 $67.6 \%$ 로 감소되었다. 최근 개에서 $\mathrm{HOST}$ 정자세포막기 능 검사의 유효한 수단이 되고 있으나 최적 $\mathrm{HOST}$ 의 조건과 정자의 반응정도는 동물종에 따 라 차이가 있는 것으로 보고되어 있다. 개에서는 $\mathrm{HOST}$ 의 초적 조건이 $100^{\sim} 150 \mathrm{mOsm}$ 에서 $45^{\sim}$ 60 분 배양이며 HOST가 개 정액 분석에 매우 유 효한 것으로 보고되었다 (Rodriguez-Gil 등, 1994). Ponce 등(1999)은 생쥐에서 $5 \mathrm{mM}$ 의 pentoxifylline 처리의 HOST 결과에서 운동성과 첨체막 온전 성 유지가 크게 개선됨을 보고하였다.

Table 5. Effect of pentoxifylline concentration on HOST of sperm after thawing

\begin{tabular}{ccc}
\hline $\begin{array}{c}\text { Pentoxifylline } \\
(\mathrm{mM})\end{array}$ & $\begin{array}{c}\text { Fresh semen } \\
(\%)\end{array}$ & $\begin{array}{c}\text { After thawing } \\
(\%)\end{array}$ \\
\hline \hline 0 & $67.6 \pm 6.1$ & $53.7 \pm 4.8^{\mathrm{b}}$ \\
1 & - & $59.5 \pm 4.5^{\mathrm{a}}$ \\
3 & - & $53.9 \pm 5.4^{\mathrm{b}}$ \\
\hline
\end{tabular}

Mean \pm SD.

${ }^{a, b}$ Means with different superscripts differ significantly $(\mathrm{P}<0.05)$.

(3) 정자생존율과 첨체막 온전성

Pentoxifylline을 0,1 및 $3 \mathrm{mM}$ 첨가 후 동결 융해한 정자의 생존율은 Table 6 과 같다. 융해

Table 6. Effect of pentoxifylline concentration on sperm viability after thawing

\begin{tabular}{ccc}
\hline $\begin{array}{c}\text { Pentoxifylline } \\
(\mathrm{mM})\end{array}$ & $\begin{array}{c}\text { Fresh semen } \\
(\%)\end{array}$ & $\begin{array}{c}\text { After thawing } \\
(\%)\end{array}$ \\
\hline \hline 0 & $82.3 \pm 1.2$ & $40.9 \pm 2.7^{\mathrm{b}}$ \\
1 & - & $43.3 \pm 4.0^{\mathrm{a}}$ \\
3 & - & $40.3 \pm 3.9^{\mathrm{b}}$ \\
\hline
\end{tabular}

Mean \pm SD.

a, b Means with different superscripts differ significantly $(\mathrm{P}<0.05)$.
후 정자생존율은 각각 40.93, 43.33 및 $40.27 \%$ 로서 $1 \mathrm{mM}$ 처리구가 대조구보다 높았다. Table 7은 pentoxifylline 처리수준에 따라 첨체막 온전 성 검사를 실시한 결과이다. 신성정액의 첨체 온전성은 $80.0 \%$ 였으며, 동결융해 후에는 pentoxifylline $0,1,3 \mathrm{mM}$ 첨가구중 $1 \mathrm{mM}$ 다른 처 리구보다 높게 나왔다. 정액동결에서 가장 문 제가 되고 있는 것은 정자 원형질막의 손상 (Watson, 1990)과 첨체 손상 (McLaughlin 등, 1992)의 증가와 생존성 저하(Alvarez와 Storey, 1993)이다. 또한 정자동결 후 수정능력의 저 하원인중에 하나는 동결융해 정자 내에 정자첨 체를 갖는 정자의 비율이다(Mock와 Zaneveld, 1987). 늑대에서는 동결융해 후 첨체손상이 아주 심한 편이다(Zalewski와 Andersen, 1983). 사람에서 pentoxifylline 처리로 첨체소실율이 감소되었고 (Esterves 등, 1998) 생쥐정자의 처 리에서 정자막의 기능 보호됨이 보고된 바 있 다(Ponce 등, 1999). Pentoxifylline 처리농도에 정자 기능에 대한 영향 조사에서 Brennan과 Holden(1995)은 사람에서 $5 \mathrm{mM}$ 처리에서 첨 체손상율의 증가를 보고하였고, 면양에서 Maxwell 등(1995)은 1 $2 \mathrm{mM}$ 과 5 $6 \mathrm{mM}$ 처리 에서 첨체온전성의 비율이 $30 \sim 43 \%$ 와 $4 \sim 6 \%$ 였 다. 특히 Paul 등(1995)는 사람에서 $6 \mathrm{mM}$ 의 처 리에 대한 반응이 개체 간에 차이가 큰 것으로 보고하였다. 개 정자의 경우 특히 동결과정 중 냉각율이 정자원형질막 손상의 큰 원인이 되며 냉각율에 대한 반응에 상당한 개체차이가 있

Table 7. Effect of pentoxifylline concentration on acrosome integrity of sperm after thawing

\begin{tabular}{ccc}
\hline $\begin{array}{c}\text { Pentoxifylline } \\
(\mathrm{mM})\end{array}$ & $\begin{array}{c}\text { Fresh semen } \\
(\%)\end{array}$ & $\begin{array}{c}\text { After thawing } \\
(\%)\end{array}$ \\
\hline \hline 0 & $80.0 \pm 2.1$ & $34.2 \pm 5.4^{\mathrm{b}}$ \\
1 & - & $39.3 \pm 5.8^{\mathrm{a}}$ \\
3 & - & $35.1 \pm 5.1^{\mathrm{b}}$ \\
\hline
\end{tabular}

Mean \pm SD.

a,b Means with different superscripts in the same row differ significantly $(\mathrm{P}<0.05)$. 
는 것으로 보고되었다(Yu 등, 2002). 뿐만 아니 라 동결감수성에 대해서도 개체차이가 크게 나 타나 있다(Platz와 Seager, 1977). 이러한 개체 차이에 대한 원인은 잘 알려져 있지 않다. 본 연구에서 pentoxifylline 첨가효과가 품종별에 차 이가 나타난 결과는 앞으로 개의 동결정액기술 개발을 위한 더 많은 연구가 필요할 부분으로 사료되었다.

\section{4. 발정주기중 난포크기와 인공수정}

발정후 $11 \sim 15$ 일간의 난포크기 변화는 Table 8 과 같으며 자연발정군과 Ring-CIDR로 발정유 기시켜 예정시각에 인공수정한 결과는 Table 9 와 같다. 자연발정군에서 수정적기 판단을 위 하여 난포발달에 대한 초음파 진단결과 발정개 시 후 11 일, 13 일 및 15 일에 난포크기는 Fig. 1 과 같이 각각 $6.5 \mathrm{~mm}, 11.5 \mathrm{~mm}$ 및 $8.0 \mathrm{~mm}$ 이었 으며 평균 좌·우측 난소의 난포수는 각각 3.3 및 4.2개였다. 자연발정개시 후 14 일과 15 일째 에 인공수정 하였고, 한편 발정유기군에서는 처리후 10 일과 11 일째에 인공수정을 실시하였 다.

Table 8. Change in follicle size after estrus

\begin{tabular}{lccc}
\hline \multirow{2}{*}{ Follicle } & \multicolumn{3}{c}{ Days after estrus } \\
\cline { 2 - 4 } & Day 11 & Day 13 & Day 15 \\
\hline \hline size(mm in dia) & 6.5 & 11.5 & 8.0 \\
\hline
\end{tabular}

Table 9. Pregnancy rate and litter size between estrus methods in bitch inseminated with frozen-thawed semen

\begin{tabular}{lccc}
\hline \multirow{2}{*}{ Estrus } & \multicolumn{3}{c}{ No. of bitch } \\
\cline { 2 - 4 } & Inseminated & Pregnant(\%) & Litter size \\
\hline \hline Natural & 7 & $5(71.4)$ & 6.6 \\
Synchronized & 4 & $3(75.0)$ & 2.6 \\
\hline
\end{tabular}

본 실험에서는 동결 융해 한 정자의 농도는 $50 \times 10^{6}$ 으로 $0.25 \mathrm{ml}$ 주입기를 이용하여 자연발
정군과 발정유기군에 자궁내 2회 수정하였다, 그 결과 자연발정구의 수태율과 평균산자수는 $71.4 \%$ 와 6.6 두였으며, 발정유기한 처리구에서 $75 \%$ 와 2.6 두였다.

\section{5. 초음파기를 이용한 임신진단}

임신일령의 기준일을 첫 교배일로 산정하여 교배 후 20 일, 25 일 및 30 일에 초음파로 진단 한 결과는 Table 10 및 Fig. 2과 같이 임신진단 에 따라 태낭의 크기가 $13.7 \mathrm{~mm}, 28.5 \mathrm{~mm}$ 및 $40.5 \mathrm{~mm}$ 로 증가되었다. 개에서 초음파기에 의 한 임신진단은 교배 후 20 일 이전은 어려움이 있고 또한 정확도가 낮은 것으로 알려져 있다

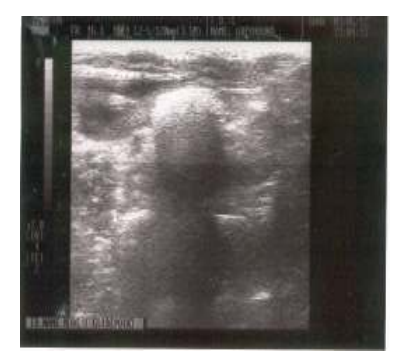

Day 11

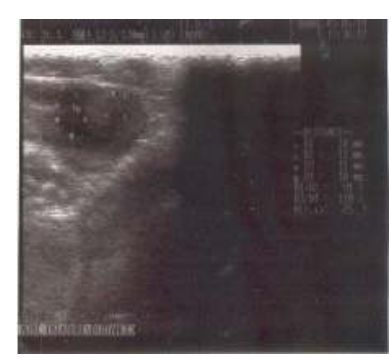

Day 13

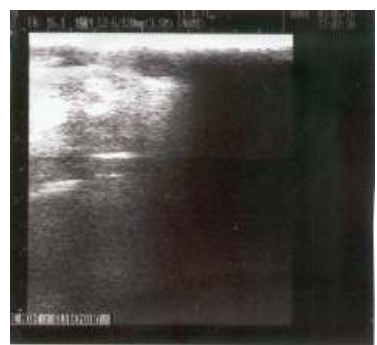

Day 15

Fig. 1. Images of follicular development after estrus. 
(Maihac 등, 1980). 일반적으로 개에서 초음파 진단기에 의한 난포 직경측정은 난포직경이 작 기 때문에 측정이 어려움이 있는 것으로 나타 나 있다(Schmidt 등, 1986). 태낭의 인지시기는 임신 20일령 이후에 인지가 가능함으로 그 이 후에 임신진단하는 것이 정확도가 높고 위험도 를 줄일 수 있는 것으로 보고되어있다(Yeager 등, 1992).

Table 10. Length of gestational sac in pregnant in bitch

\begin{tabular}{cccc}
\hline \multirow{2}{*}{ Sac } & \multicolumn{3}{c}{ Days after AI } \\
\cline { 2 - 4 } & 20 & 25 & 30 \\
\hline \hline length(mm) & 13.7 & 28.5 & 40.5 \\
\hline
\end{tabular}

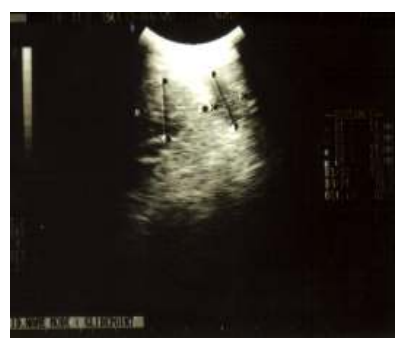

Day 20

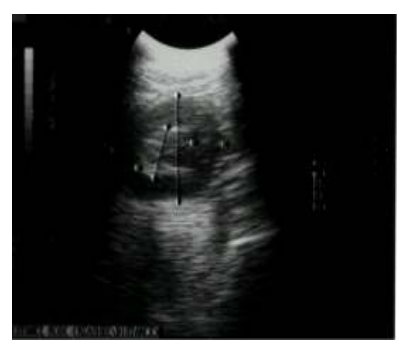

Day 25

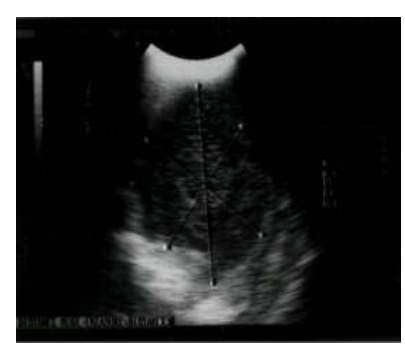

Day 30
IV. 요 약

본 연구는 개 정액 채취방법에 따른 정액성 상과 동결전 pentoxifylline의 첨가가 미치는 영 향을 조사하였고, $\mathrm{CASA}$ 를 이용하여 정자의 운 동성 측정 및 생존율, 첨체 온전성, 저삼투성 팽창화를 조사하였다. 그리고 자연발정과 발정 유기된 암캐에서 동결정액 주입의 임신율을 조 사하였다.

1. 품종별 정액성상을 조사한 결과 Beagle, English cockers spanie, Collie 및 Grey hound의 정액량과 정자 수에서 큰 차이가 없었으나, Shihtzu에서 정액량과 정자수가 유의적은 아니나 다소 적었다.

2. 동결희석액에 pentoxifylline 0,1 및 $3 \mathrm{mM}$ 첨가에서 융해 후 정자활력은 각각 46.4 , 56.4 및 $47.2 \%$ 였으며 $1 \mathrm{mM}$ 처리구가 다른 처리구보다 유의적으로 높았다.

3. 동결희석액에 pentoxifylline 첨가는 융해 후 정자의 생존성, 첨체막 온전성 및 원형 질막 온전성(HOST) 모두 유리한 결과를 나타냈으며, $1 \mathrm{mM}$ 의 첨가에서 정자의 생존 성과 기능성이 향상되었다.

4. 자연발정에서 발정개시 후 11 일, 13 일 및 15 일째 초음파기로 측정한 난포 크기는 각각 $6.5 \mathrm{~mm}, 11.5 \mathrm{~mm}$ 및 $8.0 \mathrm{~mm}$ 이였다. 배란은 $13 \sim 15$ 일 사이에 일어났다.

5. 발정유기한 개체에서 수정후 임신 20일째 부터 5일 간격으로 3 회 측정한 태낭의 크 기는 $13.7 \mathrm{~mm}, 28.5 \mathrm{~mm}$ 및 $40.5 \mathrm{~mm}$ 이었 다.

6. 자연발정과 발정을 유기한 개체에서 pentoxifylline $1 \mathrm{mM}$ 이 첨가된 정액을 동결. 융해하여 인공수정 후 임신율은 $71.4 \%$ 와 $75 \%$ 로 두 방법간에 차이가 없었으나, 자 연발정군에서 평균산자수는 6.6두였고, 발 정유군의 평균산자수는 2.6두였다.

Fig. 2. Images of gestational sac in early pregnant period. 


\section{VI. 인 용 문 헌}

1. Alvarez, J. G. and Storey, B. T. 1993. Evisence that membrane stress contributes more than lipid peroxidation to sublethal crydamage in cryoprotectant. J. Androl. 14:199-208.

2. Arnold, P., Arnold, P. W., Concannon, R., Weilenmann, M., Hubler, M., Dobeli, A., Fairburn, E., Eggenbnberger and Usch, P. 1989. Effect of duration of PMSG treatment on induction of oestrus, pregnancy rates and the complications of hyperoestrogenisum in dogs. J. Reprod. Fertil (Suppl.) 39:115-122.

3. Boucher, J. H., Foote, R. H. and Kirk, R. W. 1958. The evaluation of semen quality in the dog and the effects of frequency of ejaculation upon semen quality libido and depletion of sperm reserves. Cornell Vet. 48:67-86.

4. Brennan, A. P. and Holden, C. A. 1995. Pentoxifylline supplement cryoprotectant improves human sperm motility after cryopreservation. Hum. Reprod. 10:2308-2312.

5. Cain, J. L., Cain, G. R., Feldman, E. C., Lasley, B. L. and Stabenfeldt, G. H. 1988. Use of pulsatile intravenous administration of gonadotropinreleasing hormone to induce fertile estrus in dogs. Am. J. Vet. Res. 49:1993-1996.

6. Cain, J. L., Lasley, B. L., Cain, G. R., Feldman, E. C. and Stabenfeldt, G. H. 1989. Induction of ovulation in doges with pulsatile or continuous infusion of GnRH. J. Reprod. Fertil(Suppl.) 39: 143-147.

7. England, G. C. W. and Allen, W. E. 1992. Factors affecting the viability of canine spermatozoa. II. Effects of seminal plasma and blood. Teriogenolongy 373-381.

8. Esterve, S. C., Sharma, R. K., Thomas, A. J. Jr. and Agarwal, A. A. 1998. Cryopreservation of human spermatozoa with pentoxifylline improves the post-thaw agonist-induced acrosome reaction rate. Hum. Reprod. 13-12:3384-3389.

9. Farstad, W. 2000. Assisted reproductive technology in canine species. Theriogenlolgy 53:175-186.

10. Foote, R. H. 1964. Extenders for freezing dog semen. Am. J. Vet. Res. 25:37-39.

11. Garner, D. L., Johnson, L. A., Yue, S. T., Both, B. L. and Haugland, R. P. 1994. Dual DNA staning assessment of bovine sperm viability using SYBR-14 and propidium iodide. J. Androl. 15: 620-629.

12. Gavella, M., Lipovac, V. and Marotti, T. 1991. Effect of pentoxifylline on superoxide anion production by human sperm. Int. J. Androl. 14: 320-327.

13. Gill, H. P., Kaufman, C. F., Foote, R. H. and Kirk, R. W. 1970. Artificial insemination of beagle bitches with freshly collected, liquid-stored and frozen semen. Am. J. Vet. Res. 31:1807-1813.

14. Gunzel, A. R. 1986. Sperm collection, evaluation, preservation and artificial insemination in the dog. Tierarztl Prax. 14:275-282.

15. Harrop, A. E. 1954. Artificial insemination of a bitch with preserved semen. Brit. Vet. J. 110: 194-195. 424-425.

16. Kumi-Diaka, J. 1993. Subjecting canine semen to the hypo-osmotic test. Theriogenology 39:1279- 1289.

17. Mailhac, J. M., Chaffaux, S., Legrand, J. J., Carlier, B. and Hettz F. 1980. Diagnostic de la gestation chez la chatte: Utilisation de l'echographie. Recl. Med. Vet. Ec. Alfort. 156:899-907.

18. Maxwell, W. M. C., Robinson, S. J., Roca, J., Molinia, F. C., Sanchez-Partida, L. G. and Evans, G. 1995. Motility, acrosome integrity and fertility of frozen ram spermatozoa treated with caffeine, pentoxifylline, cAMP, 2-deoxyadenoine and kallikrein. J. Reprod. Fertil. 7:1081-1807.

19. McLaughlin, E. A., Ford, W. C. L. and Hull, M. G. R. 1992. Motiliity characteristics and membrane integrity of preserved human spermatozoa. J. Reprod. Fertil. 95:527-532.

20. Mckinney, K. A., Lewis, S. E. M. and Thompson, W. 1996. The effects of pentoxifylline on the generation of reactive oxygen species and lipid peroxdation in human spermatozoa. J. Androl. 28:15-20. 
21. Mock, S. R. and Zaneveld, L. J. 1987. Acrosomal enzymes and ultrastructuse of unfrozen and cryotreated human spermatozoa. Gamete Res. 18: 375-383.

22. Nassar, A., Mahony, M., Srisombut, C., Lin, M. H. and Oehninger, S. 1999. Pentoxifylline stimulates various sperm motion parameters and cervical mucus penotrability in patients with asthenozoospermia. J. Androl. 31:9-13.

23. Olar, T. T., Browen, R. A. and Pickett, B. W. 1989. Influence of extender, cryopreservation and seminal processing procedures on post thaw motility of canine spermatozoa frozen in straws. Theriogenology. 31:451-461.

24. Olson, S. N., Bowen, R. A., Behrendt, M. D., Olson, J. D. and Nett, T. M. 1984. Coccentration of testosterone in canine serum during late anestrus, proestrus, estrus, and early diestrus. Am. J. Vet. Res. 45:145-148.

25. Paul, M., Sumpter, J. P. and Lindsay, K. S. 1995. Action of pentoxifylline directly on semen. Hum. Reprod. 10:354-359.

26. Pinto, C. R., Eilts, B. E. and Paccamonti, D. L. 1998. The effect of reducing hindquarter elevation time after artificial insemination in bitches. Theriogenology. 50:301-305.

27. Ponce, A. A., Fiolde Cuneo, M., Ruiz, R. D., Vincenti, L. M., Stuiz, G. and Lacuara, J. L. 1999. Influence of pentoxifylline on sperm membrane functional integrity. Arch. Androl. 43:77-84.

28. Platz, C. C. and Serger, S. W. 1977. Successful pregnancies with concentrated frozen canine semen. Lab. Anim. Sci. 27:1013-1016.

29. Rees, J. M., Ford, W. C. L. and Hull, M. G. R. 1990. Effect of caffeine and of pentoxifylline on the motility and metabolism of human spermatozoa. J. Reprod. Fertil. 90:147-156.

30. Rodriguez-Gil, J. E., Montserrat, A. and Rigau, T. 1994. Effects of hypoosmotic incubation on acrosome and tail structure on canine spermatozoa. Theriogenology. 815-829.

31. Rota, A., Strom, B., Linde-Forsberg, C. and
Rodriguez-Martinez, H. 1997. Effects of equex STM paste on viability of frozen-thawed dog spermatozoa during in vitro incubation at $38^{\circ} \mathrm{C}$. Theriogenology. 47:1093-1101.

32. Schmidt, S., Chrag, D. S. and Giese, E. 1986. Ultraschalliagnostik inder gynakologie beim kleintier. Tierarztl. Prax. 14:123-141.

33. Seager, S. W. and Fletcher, W. S. 1973. Progress on the use of frozen semen in the dog. Vet. Rec. 92:6-10.

34. Shille, V. M., Thatcher, M. J., Lloyd, M. L., Miller, D. D., Seyfert, D. F. and Sherrod, J. D. 1989. Gonadotrophic control of follicular development and the use of exgenous gonadotrophis for induction of oestrus and ovulation in the bitch. J. Reprod. Fertil(Suppl.). 39:103-113.

35. Stefanovich, V. 1973. Effect of 3,7-dimethyl-1-(5oxohexyl)-xanthine and 1-hexy1-3,7-dimeth1-xanthine on cyclic AMP phophodiesterase of the human umbilical cord vessels. Res. Com. Chem. Pathol. Pharmacol. 5:655-662.

36. Takagi, H., Kurihara, A., Inoue, T., Nakamura, I. and Kimura, M. 2001. Investigation of usefulness of sperm analyses in dog for male fertility study. Toxicological Sci. 25:313-321.

37. Watson, P. F. 1990. Artificial insemination and the preservation of semen. In: Lamming, G. E. (ed), Marshalls Physiology of Reproduction, Reproduction in the Male (4th ed.) Chuchill Livingstone, Edinburgih, UK pp. 747-869.

38. Wang, R., Sikka, S. C., Veeraragavan, K., Bell, M. and Hellstrom, M. D. 1993. Platelet activating factor and pentoxifylline as human sperm cryoprotectants. Fertil. Steril. 60:711-715.

39. Yeager, A. E., Mohammed, H. O. and MeyersWallen, V. 1992. Ultrasonographic appearance of the uterus, placenta, fetus and fetal membranes throughout accurately time pregnancy in Beagles. Am. J. Vet. Res. 53:342-351.

40. Yovich, J. L. 1993. Pentoxifylline: action and application in assisted reprouction. Hum. Reprod. 8:1786-1791. 
41. Yu, I., Songsasen., N., Godke, R. A. and Leibo. 2002. Difference among dogs in response of their spermatozoa to cryopreservation using cooling various and warming rats. Cryobiology 44:62-78.

42. Zalewski, W. and Andersen, B. K. 1983. Acrosomal damage caused and processing of frozen semen from the silver fox (Vulpes argenteus) and the blue fox (Alopex lagppus). Zuchthygienw. 18: 22-26.
43. 이영락, 강태영, 최상웅. 2003. 개에서 발정유도 가 인공수정효율에 미치는 영향. 한국수정란이식 학회지. 18:1:61-68.

(접수일자 : 2005. 9. 6. / 채택일자 : 2005. 12. 12.) 